\title{
EL MATRIMONIO DE LA REINA LEODEGUNDIA
}

\author{
Antonio Ubieto Arteta (†)
}

La reina Leodegundia ha pasado a la historia fundamentalmente por ser la primera mujer que al casarse ha originado unos versos, que contienen notaciones musicales, en su primera estrofa, lo que convierte tales versos en el canto «epitalámico más antiguo de Europa»".

La composición la integran ochenta y cinco versos «rítmicos y de género trocaico, distribuidos en estrofas de tres versos, sin rima. Cada uno de éstos se halla formado por dos hemistiquios de seis sílabas en el primero, siete en el segundo y ocho en el tercero; el último hemistiquio es cataléctico, estando su última sílaba suplida por la pausa final ${ }^{2}$.

Finalmente, se ha observado que con las letras iniciales de cada estrofa se lee en acróstico la frase Leodegundia pulcra Ordonii filia.

El problema fundamental lo ha planteado el hecho de que se desconozca el nombre del marido, aunque se ha supuesto que podría serlo tanto Sancho Garcés I, como el rey Fortún Garcés ${ }^{3}$.

A estas primeras posibles identificaciones, conforme iban apareciendo más textos, se unían otras nuevas.

Fray Justo Pérez de Urbel creyó que el matrimonio de Leodegundia se produjo entre 850 y 860 con Jimeno, «el padre de Garća Jiménez e Iñigo Jiménezs ${ }^{4}$.

Naturalmente, esta identificación fue pronto rechazada, llegando dubitativamente a la conclusión de que «Leodegundia pudo ser segunda esposa de García Iñ́guez o de Fortún Garcés antes del 858, cuando Oviedo y

'Lacarra, J.M., *Textos navarros del Códice de Rodaw, en Estudios de Edad Media de la Corona de Aragón, 1, Zaragoza 1945, p. 271-275.

2 Véase J.M. LACARRA, *Textos», p. 271.

${ }^{3}$ Véase Alfonso Cotarelo, Historia de Alfonso III el Magno, Madrid 1933, p. 139 y 145. Ferran VaLls y TABErner, Las genealoglas de Roda, en aDiscurs llegits en la R. Academia de Buenas Letras* de Barcelona en la solemne recepción de D.- (Barcelona 1929). p. 18.

4 Véase J. PÉrez De Urael, «Lo viejo y lo nuevo sobre el origen del reino de Pamplonan. Al-Andalus, 19. Madrid-Granada 1954, p. 31-32; edimenos y Velas en Portugals, Revista Portuguesa de História, 5. Coimbra 1951, p. 482-483. 
Pamplona se acercaron en vísperas de Albelda [...]. Pero he escrito "pudo ser". ¿Lo fue? Sabemos en verdad tan poco de esa etapa de la historia navarra que no seré yo quien se atreva a lanzar sino vacilantes y problemáticas conjeturas $"^{5}$.

Ha existido, en cambio, una postura más cauta, que no ha hecho ninguna suposición, dando únicamente la edición del texto y los comentarios pertinentes, sin indicar sospecha alguna ${ }^{6}$.

Dejando aparte el ya resuelto problema de que Leodegundia era de estirpe real, pues los versos lo indican en su contexto, y de que Leodegundia fue reina, pues el encabezamiento de tales versos es coetáneo en la escritura al resto, sigue en pie la identificación del monarca con el que casó tan cantada reina.

Existe desde siempre un texto que nunca se ha relacionado con Leodegundia, quizás porque contiene una contradicción histórica, pero que parece ser la clave para solucionar este pequeño problema de la historia navarra primitiva.

Un eximio navarro escribió en el siglo XII la que quizás podemos considerar primera Historia amplia de España: me refiero a Rodrigo Jiménez de Rada, arzobispo de Toledo. En su obra acopió muchos materiales cuyo origen hoy desconocemos.

En la parte relativa a Navarra sacó de no sabemos dónde unas noticias, que colocó donde le pareció oportuno, aunque en algún caso no acertó. Por ejemplo, encontró noticias sobre la variación del «Camino de Santiago» cuya fuente atribuía a un incierto rey llamado Sancho. Y el Toledano lo atribuyo al rey Sancho el Mayor (1004-1035), con evidente desacierto, ya que hay que atribuirlo al rey Sancho Garcés I (905-925)?

A estas conclusiones se ha podido llegar gracias a la comparación del texto en las diversas fuentes que lo transmiten.

Lo mismo parece que ocurre con otra noticia relativa a los orígenes de Navarra, que no ha sido destacada por los historiadores.

El Toledano hace la historia del rey Ordoño II de Asturias (914-924), dando abundantes detalles que permiten identificarlo plenamente: la batalla de Muez (920), la de Valdejunquera (924), la prisión de los obispos Dulcidio de Salamanca y Hermogio de Tuy, y otras más que no tienen relación con Navarra. Al final añade esta frase: «Et foederatus Garsiae Enechonis

5 Véase C. SÁNChEz ALBORNOZ, «Problemas de la historia navarra del siglo IX», Cuadernos de Historia de España, 25-26, Buenos Aires 1957, p. 34-36.

6 Véase J.M. Lacarra, «Las relaciones entre el reino de Asturias y el reino de Pamplonas, en Estudios sobre la monarquía asturianaw, Oviedo 1949, p. 234-235; Historia politica del reino de Navarra desde sus origenes hasta su incorporación a Castilla, 1, Pamplona 1972, p. 99-101.

7 Véase mi artículo titulado «Una variación en el Camino de Santiago*, Estudios de Edad Media de la Corona de Aragón, 9, Zaragoza 1973, p. 49-69. 
Aristae, principi Navarrorum, filiam eius nomine Sancia duxit uxorem. Post etiam cepit Anagarum quod olim T(r)icium vocatabatur, et Vicariam quae ex eo nomen dicitur habuisse, quod Gothorum tempore sedes iudicii habebatur ${ }^{8}$.m

La noticia de la federación con «García Iñíguez Arista, príncipe de los Navarros, tomando como mujer a su hija Sancha» está seguida de la conquista de Nájera (llamada antes Tricio) y la de Viguera, que se documentan en el año 920.

El error está en identificar a la mujer de Ordoño II con una hija de García Iñiguez Arista, ya que está abundantemente identificada por las crónicas como hija de Sancho Garcés I y de la reina Toda.

Los textos son terminantes a este respecto:

a) «Sancio Garseanis, obtime imperator, accepit uxor Tota Asnari et genuit Garsea rex, et domna Onneca, et domna Sanzia et domna Urraca...

„Domna Sanzia fuit uxor Ordonii imperatoris. Postea habuit virum Albaro Harramelliz de Alaba. Demumque fuit uxor Fredenando comitis $^{9}$."

b) «Tunc sortitus est filiam eius in uxorem nomine Sanciam convenientem sibi ${ }^{10} . n$

c) La Crónica Najerense habla de este matrimonio dos veces: la primera repite lo mismo que las fuentes señaladas en $b$ ), con la misma atribución. Pero en la segunda es terminante. Al hablar del conde Fernán González precisa que «unde cum Sanctia eisdem regis Garsee sorore, que prius Ordonii regis Legionis, postea comitis Albari Harrameliz de Alava extiterat uxor, habens nesciente fratre colloquium liberatus est dato prius eidem sacramento, quod si eum inde educeret, eam duceret in uxorem. Quod et fecits ${ }^{11}$.

Así, la Najerense realiza la atribución de la paternidad a Sancho Garcés I, como el resto de la documentación.

8 Véase R. JMÉnEz DE RADA, De rebus Hispaniae, en «Textos Medievales», 22, Valencia 1968, p. 97.

9 Véase Genealogia de Roda, ed. LAcarra, Textos, p. 236-237, núm. 13 y 14.

10 Véase SAmpiro, en fray Justo Pérez DE URBEL, Sampiro. Su crónica y la monarquía leonesa en el siglo X, Madrid 1952, p. 317. Se refiere a Ordoño II. Pero equivoca el nombre del padre, al que llama García, hijo de Sancho, lo que lo diferencia del texto del Toledano.

Encontramos la misma noticia en Historia Silense, ed. fray Justo Pérez de UrBel y A. Gonzílezz Ruzz Zorrilla, Madrid 1959, p. 164-165.

II Véase Crónica Najerense, ed. A. Ubirto ARTETA, en «Textos Medievales», 15, Valencia 1966, p. 72 y 78 . 
Si comparamos los textos cronísticos conservados con los del Toledano resultaría que en el primero aparece claramente Sancha como mujer de Ordoño II, e hija de Sancho Garcés I en el más antiguo (Genealogías de Roda); como hija de un García Sánchez, en Sampiro; y una vez como hija de un García y otra como hija de Sancho Garcés, en la Najerense. Pero en ninguna de las tres está la atribución de la paternidad a García Iñíguez Arista, como lo hace el Toledano.

Como lo documentado es que Sancha fue hija de Sancho Garcés II y la reina Toda, hay que aceptar que ha existido una noticia histórica suelta, recogida en Sampiro, Historia Silense y primera versión de la Najerense que habla del matrimonio de una hija de un príncipe navarro llamado García con un rey llamado Ordoño.

Aproximadamente diria: «Rex Ordonius cepit/dedit in uxorem filiam Garsiae Ennechonis Aristae, principi Navarrorum.»

Una noticia como ésta permitiría adaptarla según los conocimientos de cada cronista. Al saber que Ordoño II casó con Sancha, Sampiro y sus continuadores tenían que eliminar el patronímico «Enechonis Aristae», ya que acababan de aludir a Sancho Garcés I. Pero el Toledano conservó intacto el nombre, lo que nos permite sospechar que la reina Leodegundia cas6́ con el rey pamplonés García Iñíguez, siendo hija de Ordoño I de Asturias (850-866).

El rey García Iñíguez sucedió a su padre el año 851 ; en 859 fue cogido prisionero por los normandos (se cita en documento de 880$)^{12}$. En parte fue coetáneo de Ordoño I de Asturias.

Pero lo más interesante es que el posible matrimonio de Leodegundia con el pamplonés García Iníguez respondiera a la alianza suscrita hacia 860 por García Iñíguez y Ordoño I de Asturias, texto al que respondería esta noticia.

«En este año [860] salió en campaña con la aceifa el emir Muhammad contra Garsiya ibn Wannaqo, señor de Pamplona, después que éste se hubo rescatado de la cautividad de los Maŷus, pues [García] se alió con Urdun ibn Idfuns, rey de Yilliqiya, para hacer una incursión por tierras del Islam ${ }^{13}$.

Pero por la fecha de este matrimonio de Leodegundia con García Iñiguez habrá que aceptar que fue por lo menos el segundo del monarca.

12 LACARRA, Historia de Navarra, 1, p. 81-82.

13 Véase E. LeVI Provençal y E. Garcí Gómez, "Textos inéditos del "Muqtabis" de Ibn Hayyan sobre los orígenes del reino de Pamplonax, en Al-Andalus, 19, Madrid-Granada 1954. p. 308-309, núm. 12.

La reina Urraca del Toledano (De rebus Hispaniae, lib. V, cap. XXI) no fue mujer de este rey Garcia Iñíguez de Pamplona sino de su homónimo ade otras partes del reinos. 